\title{
FATAL INTRA-PERITONEAL BLADDER RUPTURE DUE TO BLOCKED CATHETER IN A PARAPLEGIC
}

\author{
By S. Vaidyanathan, M.S., M.Ch., M. S. Rao, M.S., A. Saleem, M.S., \\ C. L. Subudhi, M.S., L. J. Rajendran, M.S. and V. V. Shrikhande, M.S. \\ Departments of Urology, and General Surgery, Post-graduate Institute of \\ Medical Education and Research, Chandigarh, India
}

\begin{abstract}
A female paraplegic developed intraperitoneal rupture of urinary bladder seven weeks after institution of indwelling urethral catheter drainage. Blockage of the catheter precipitated this fatal event. Oliguria after an initial encouraging urinary output despite adequate fluid replacement led us to suspect bladder rupture which was confirmed by urgent cystography. Although emergency laparotomy to repair the rent in the bladder was performed, she succumbed to gram-negative septicemia. Other hazards of indwelling urethral catheter drainage even for short periods are highlighted (though the above complication itself is admittedly rare) with an oft re-emphasised plea to consider earlier the alternative modality of intermittent catheterisation or pharmacotherapy in female patients.
\end{abstract}

Key words: Paraplegia-Mortality; Rupture-Urinary bladder; Dangers of indwelling urethral catheters.

THE hazards of long-term indwelling urethral catheter drainage in paaplregics are well known (Ascoli, I968; Hardy, I968; Kyle, I968). But such a form of treatment is still being practised (Cook \& Smith, 1968; Ascoli, 1975; Melzer et al., 1976; Terbizan \& Zurbecky, 1976) so that a small but significant number of paraplegics are being sent home with indwelling urethral catheters. In a female, the indwelling urethral catheter could lead to erosion of the ventral urethral wall leading thereby to fistula-formation and incontinence (Gibbon, 1974). Catheters when blocked can lead to overdistension of bladder predisposing rarely to its rupture. Such a calamity when unsuspected on account of its rarity, proves fatal from the inevitable sepsis as a result of delayed detection. Although spontaneous rupture of diseased bladders or vesical diverticulae have been reported and reviewed before in non-paraplegics (Rao et al., I977), Thompson (I965) reported in one of seven cases in his series occurring perhaps for the first time in a neurogenic bladder. We report this fatal complication in a female paraplegic on indwelling urethral catheter drainage.

P. D. (A424826) a 50-year-old female was admitted to the neurosurgical service in May 1978 with the complaints of backache, inability to walk and retention of urine of 8 days' duration. Indwelling urethral catheter drainage was established. Kyphosis with radiological confirmation of destruction of the body of the 9th thoracic vertebra were noted. With a provisional diagnosis of Pott's paraplegia, laminectomy of $\mathrm{T}^{\mathbf{1 0}}, \mathrm{T}^{\mathbf{9}}$ and $\mathrm{T}^{8}$ vertebrae was performed. Blood urea during this admission was $39 \mathrm{mg}$ per cent. She was prescribed streptomycin, isoniazid and PAS on the presumptive diagnosis of spinal tuberculosis. Postoperatively there was no appreciable improvement in her neurological status. Trial off catheter was unsuccessful. Urologic consultation was not obtained. She was discharged on indwelling urethral Foley catheter drainage and returned to the 
hospital 22 days later and again after a further I9 days with a blocked catheter which was replaced with a new one by the neurosurgical team on each occasion. One day prior to the present emergency admission, the relatives noticed that the catheter was not draining urine. There was no history of abdominal trauma or any catheter-tug immediately preceding the stoppage of urine. She was brought to this hospital which is about 50 miles from her village. There is no direct bus service from her home area to our place and the initial phase of that journey had to be undertaken by bullock cart. She had fever with chills and vomited once on her way to the hospital.

At emergency admission, heart rate was 120/minute; respiration: 40/minute; blood pressure was unrecordable. The abdomen was mildly distended but no rigidity or tenderness was elicited. Bladder was not palpable. Bowel sounds were audible. Liver dullness was not obliterated. Sensory level was $\mathrm{T}_{\mathbf{g}}$. Motor power in the lower limbs was Grade I. She had a pressure sore over the sacrum. The urethral catheter was found to be blocked and was changed. With a preliminary diagnosis of septic shock from a blocked catheter, she was administered $2 \mathrm{G}$ of hydrocortisone sodium succinate intravenously. A loading dose of $80 \mathrm{mg}$ gentamicin was given intramuscularly and $40 \mathrm{mg}$ repeated every 8 hours.

\section{Investigations}

Blood urea: $42 \mathrm{mg}$ per cent; random blood sugar: $70 \mathrm{mg}$ per cent; serum electrolytes (in mEq/litre) $\mathrm{Na}: \mathrm{I} 26, \mathrm{~K}: 3 \cdot 8, \mathrm{Cl}: 87, \mathrm{HCO}_{3}: 23, \mathrm{Hb}: \mathrm{I} 2 \cdot \mathrm{I} \mathrm{G}$ per cent, W.B.C. count: $19,600 / \mathrm{mm}^{3}$ with polymorphs 80 per cent and lymphocytes 20 per cent. Electrocardiogram showed sinus tachycardia with no evidence of a cardiac cause for her hypotension. Chest X-ray was normal. Plain X-ray of the abdomen showed no free air under the domes of diaphragm. Distended coils of small intestine were noticed. Blood culture (taken after the administration of antibiotic and reported posthumously) was sterile.

After the urethral catheter was changed it drained $550 \mathrm{ml}$ of slightly bloodstained urine during the next seven hours. She was transfused four units of blood apart from crystalloids. But over the subsequent 6 hours the urine output was only $200 \mathrm{ml}$ despite adequate fluid replacement. Hence urgent cystography was performed to confirm the integrity or otherwise of the bladder. Cystogram showed an intraperitoneal rupture (Fig. I). Emergency laparotomy was performed twenty hours after admission. There was a $4 \mathrm{~cm}$ long rent in the dome of the bladder and adjoining peritoneum which was repaired in two layers after freshening its edges which appeared bruised but not diseased. The bladder wall was supple, muscular and untrabeculated although slightly thickened. The viscus appeared to be of adequate capacity. Its mucosa showed occasional flakes and haemorrhagic areas of mild cystitis. Peritoneal toilet was achieved. Suprapubic cystostomy was established. Hypotension persisted throughout with the systolic pressure never rising above $80 \mathrm{~mm} \mathrm{Hg}$. She developed cardiac arrest three hours postoperatively from which she could not be revived.

\section{Discussion}

Acute abdomen in a paraplegic could prove to be a baffling entity. Establishing the accurate diagnosis promptly may prove to be a challenge to the physician taking care of paraplegics and will require the development of radiological facilities without delay. Unrecognised visceral perforation often proves to be fatal in a 


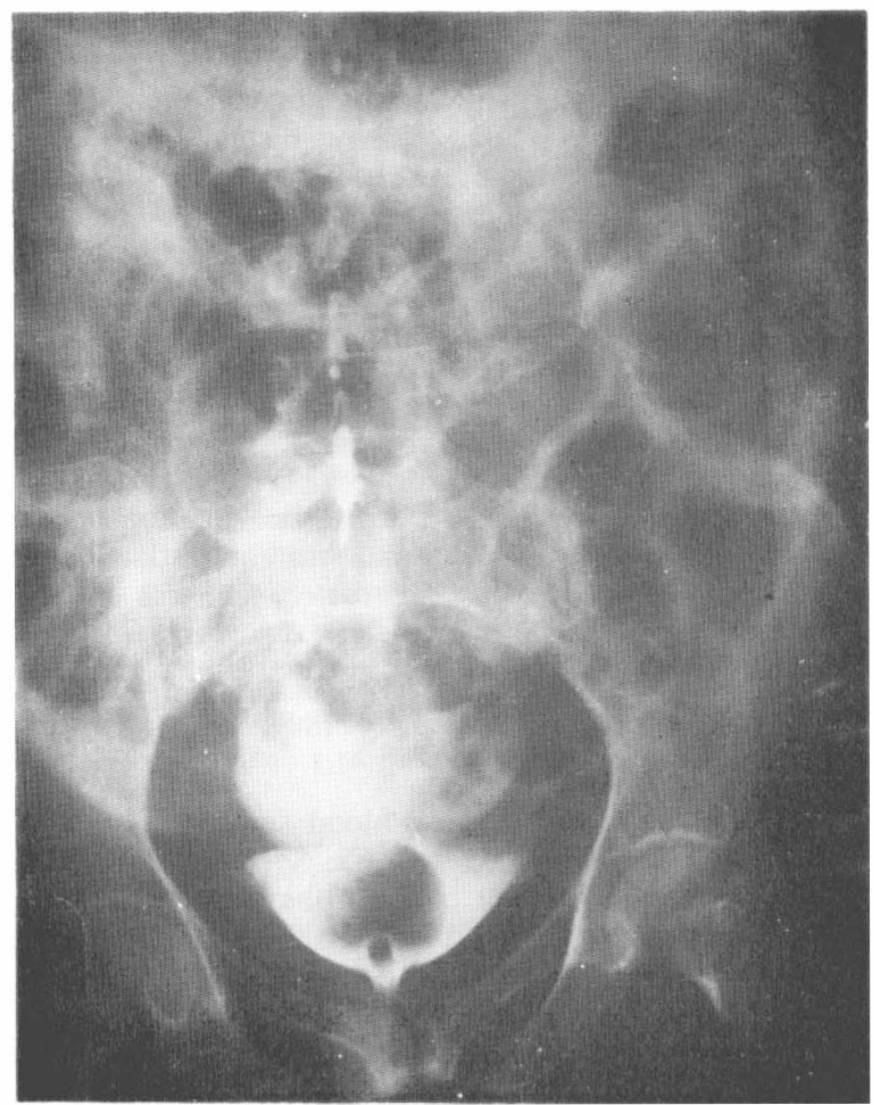

FIG. I

Cystogram shows extravasation of Contrast into the peritoneal cavity outlining the bowel-loops.

paraplegic (Walsh et al., 1974). Although it is said that increased abdominal muscle tonus, referred pain to shoulders, sensation of being sick, etc., should suggest an abdominal catastrophe in a paraplegic, it is understandably difficult to precisely diagnose the nature of such a calamity. Visceral sensation from the abdominal organs is said to occur by vagal transmission and earlier studies have shown that even tetraplegics are often able to appreciate hunger pangs, abdominal dread, etc. (Crawford \& Frankel, 197I). But our patient with sensory level at $\mathrm{T}_{9}$ surprisingly did not complain of abdominal pain or referred pain to shoulder tip. Initial diagnosis in the presence of a blocked catheter and hypotension was gramnegative septicaemia. Urinary output of $500 \mathrm{ml}$ over the first 7 hours of hospital stay diverted our attention temporarily from the bladder rupture. Considered in retrospect, such a phenomenon has been known to occur with a rent high-up on the bladder dome or when the same is plugged by omentum or a perivesical fat pad. Both these would allow some degree of bladder filling but permit urine to spurt out periodically in small increments when the viscus is near full.

Although the tip of a Foley catheter, when kept for long periods, could burrow its way totally through a diseased bladder wall (Hughes et al., I973), a 4-cm long linear rent at the bladder dome suggests rupture due to overdistension in our case. 
A change of catheter for relief of blockage prior to operation prevented absolute confirmation of this concept. Although tuberculosis of the bladder has been reported to be a predominant cause in a review of spontaneous vesical rupture cases by Bastable et al. (1959), this applied to fibrosed, rigid, contracted bladders. Bladder malignancy was the second frequent cause of this phenomenon in the same report.

Clean, atraumatic intermittent catheterisation has been practised in cases of neurogenic bladder dysfunction (Lapides et al., 1972). Although transurethral resection of bladder neck, Otis urethrotomy and simple repeated urethral dilatation have been advocated in female paraplegics (Elsaesser \& Stoephasius, 1972; Jameson, I976) some of these procedures could occasionally lead to urinary incontinence. Pharmacological agents such as phenoxybenzamine have also been used but such pharmacotherapy would first require long-term trials as well as cheap and ready availability in developing countries before an opinion on their role in treatment gets properly defined.

Since urological consultation was not sought for earlier, investigations like I-VP, cystometry, urethral pressure profilometry, etc., were not performed for a baseline assessment of the urinary tract component of her neurological problem. In this context, we wish to emphasise the need for a multi-disciplinary approach in the care of paraplegics as advocated by Guttmann (1978) for optimal patient care particularly in institutions like ours where care of spinal injury or disease problems does not form as yet a wholetime occupation for the treating units concerned. We have found clean, non-sterile intermittent catheterisation performed either by the patient or by the relatives to be satisfactory even when practised for long periods (for over four years in an occasional case). Hence our policy has been to avoid as far as possible, discharging any paraplegic to the home environment on indwelling urethral catheter drainage (Rao et al., 1979). In male paraplegics, when indicated, we have been performing external urethral sphincterotomy (Rao et al., 1977-78; Rao et al., 1978). But in females for reasons already mentioned, we have been inclined to refrain from a transurethral resection of bladder neck or urethrotomy. Moreover, our female patients or attendants have had no difficulty adapting quickly to intermittent catheterisation regimen.

\section{SUMMARY}

Fatal intraperitoneal rupture of urinary bladder in a female paraplegic due to blocked catheter is presented to emphasise the hazards of sending paraplegics on indwelling urethral catheters to home environments in developing countries where delay in transportation to centres with interest and experience in paraplegic and quadraplegic care occur. Clean, atraumatic intermittent catheterisation could be used as the better alternative with pharmacological agents to promote bladder emptying holding bright prospects for the future. A multi-disciplinary approach towards management of such cases from the earliest occasion would help reduce complications related to body-systems unfamiliar to the initial treating group. This is particularly true when the concerned staff at a centre like ours are not, as yet, dealing with these patients on a whole time basis.

\section{RÉSUMÉ}

On a décrit une rupture fatale intra-péritonéale de la vessie urinaire d'une paraplégique due à une sonde obstruée, en vue de souligner les risques que l'on court en renvoyant chez eux les paraplégiques pourvus d'une sonde à demeure, dans les pays en développement 
où il peut se produire un certain retard dans le transport des malades aux centres possédant l'expérience et les moyens de soigner les cas de paraplégie et de quadruplégie. On peut adopter un cathétérisme intermittent propre et atraumatique avec des agents pharmacologiques facilitant l'évacuation de la vessie; ceci représente une meilleure solution avec de très bonnes chances de succès à l'avenir. Une approche multi-disciplinaire au traitement de tels cas dès les premiers signes contribuerait à réduire les complications relevant des systèmes de corps qui ne sont pas bien connus du groupe de spécialistes qui a commencé le traitement initial. Ceci est d'autant plus vrai que le personnel concerné d'un centre comme le nôtre ne s'occupe pas encore de tels malades à plein-temps.

\section{ZUSAMMENFASSUNG}

Tödliche intraperitoneale Zerreissung der Harnblase in der Paraplegie einer Frau durch dem blokierten Katheter ist hier beschrieben um die Gefahren, verursacht durch den Versand der Paraplegie auf dem darinverweilenden urethralen Kathetere nach Heimumgebung in Entwicklungsländern, zu betonen, wo eine Verzögerung nach Instituten, die Interesse und Erfahrung in paraplegischer und quadruplegischer Sorge haben, stattfindet. Saubere, untraumatische, unregelmässige Katheterisierung konnte als bessere Alternative mit pharmakologischer Agense zur Entleerung der Harnblase verwendet werden; diese Methode hat gute Aussichten für die Zukunft. Ein Multi-disziplinärer Versuch zur Behandlung solcher Fälle von frühester Zeit an wird zur Minderung der Komplikationen bezüglich der Körpersysteme, die der Anfangsbehandlungsgruppe unbekannt sind, beitragen. Das gilt besonders wenn das betreffende Personal bei einem Institut wie unser solche Patienten noch nicht auf ganzzeitiger Basis behandelt.

\section{REFERENCES}

AscolI, R. (1968). The indwelling catheter in paraplegics. Paraplegia, 6, I7-2I.

Ascoli, R. (I975). The urological treatment of paraplegic patients at home. Paraplegia, I2, 260-262.

Bastable, J. R. G., Dejode, L. R. \& Warren, R. D. (I959). Spontaneous rupture of bladder. Brit. F. Urol., $3 \mathbf{1}, 78$.

Cook, J. B. \& SMITH, P. H. (I968). Long-term urethral catheterisation after spinal injury. Paraplegia, 6, I I-I6.

CRAWFord, J. P. \& Frankel, H. L. (I97I). Abdominal visceral sensation in human tetraplegia. Paraplegia, 9, I53-I 58.

EISAESSER, E. \& STOEPHASIUS, E. (1972). Urological operations for improvement of bladder voiding in paraplegic patients. Paraplegia, 10, 68-77.

Gibbon, N. O. K. (I974). Later management of the paraplegic bladder. Paraplegia, I2, 87-9I.

GuttManN, L. (1977-78). Total responsibility of the surgeon in the management of traumatic spinal paraplegics and tetraplegics. Paraplegia, 15, 285-292.

Hardy, A. G. (1968). Complications of the indwelling urethral catheter. Paraplegia, 6, 5-IO.

Hughes, J. P., Gambee, J. \& Edwards, C. (1973). Perforation of the bladder: a complication of long-dwelling Foley catheter. F. Urol., 109, 237.

JAMESON, R. M. (1976). Urological management in non-traumatic paraplegia. Paraplegia, I3, 228-234.

Kyle, E. W. (I968). The complications of indwelling catheters. Paraplegia, 6, I-4.

LAPIDES, J., Diokno, A. C., Silber, S. J. \& Lowe, B. S. (I972). Clean, intermittent selfcatheterization in the treatment of urinary tract disease. F. Urol., 107, 458-461.

Melzer, M., Ohry, A., Hertz, M. \& RozIN, R. (I976). The status of the urinary tract in a survey of 92 cases with neurogenic bladder. Paraplegia, 14, 213-219.

Rao, M. S., Saleem, A., Vaidyanathan, S. \& Bapna, B. C. (I977). Spontaneous intraperitoneal rupture of bladder diverticulum due to blocked catheter. Ind. F. Surg., 39, 36-37.

RaO, M. S., Bapna, B. C., Vaidyanathan, S., Gupta, C. L., Bhat, V. N., Reddy, M. J., RAO, K. M. K. \& HARIWIR SINGH (I977-78). Topical or no anaesthesia for external urethral sphincterotomy in neurogenic vesical dysfunction due to spinal injury. Paraplegia, 15, 226-229. 
RaO, M. S., Bapna, B. C., Vaidyanathan, S., Bhat, V. N., Gupta, C. L., Reddy, M. J. \& RAO, K. M. K. (I978). External urethral sphincterotomy in neurogenic bladder dysfunction from spinal injury. Ind. F. Surg., 40, 20I-204.

RaO, M. S., Bapna, B. C., Reddy, M. J., RaO, K. M. K., Subudhi, C. L., Rajendran, L. J., Shrikhande, V. V., Sharma, S. K. \& Vaidyanathan, S. (I979). Non-sterile atraumatic intermittent catheterization in neurogenic and non-neurogenic bladder dysfunction. Ind. F. Surg. 41, 198-204.

Terbizan, A. \& Zurbecky, G. (I976). Uro-check in paraplegics. Paraplegia, 14, 47-49.

Thompson, I. M., Johnson, E. L. \& Ross, Jr., G. (1965). The acute abdomen of unrecognized bladder rupture. Arch. Surg., 90, 37I-374.

Walsh, J. J., NuSEIBEH, I. \& EL-MAZRI, W. (I974). Perforated peptic ulcer in paraplegia. Paraplegia, II, 310-313. 